University of Rhode Island

DigitalCommons@URI

\title{
Peptide-Pulsed Dendritic Cells Induce the Hepatitis C Viral Epitope-Specific Responses of Naïve Human T Cells
}

Sasmita Mishra

Phyllis T. Losikoff

Alyssa A. Self

Frances Terry

Matthew T. Ardito

See next page for additional authors

The University of Rhode Island Faculty have made this article openly available.

Please let us know how Open Access to this research benefits you.

This is a pre-publication author manuscript of the final, published article.

Terms of Use

This article is made available under the terms and conditions applicable towards Open Access Policy Articles, as set forth in our Terms of Use.

\section{Citation/Publisher Attribution}

Mishra, S., Losikoff, P. T., Self, A. A., Terry, F., Ardito, M. T., Tassone, R.,...Gregory, S. H. (2014). Peptidepulsed dendritic cells induce the hepatitis $C$ viral epitope-specific responses of naïve human $T$ cells. Vaccine, 32(26), 3285-3292. doi: 10.1016/j.vaccine.2014.03.083

Available at: http://dx.doi.org/10.1016/j.vaccine.2014.03.083

This Article is brought to you for free and open access by the Institute for Immunology and Informatics (iCubed) at DigitalCommons@URI. It has been accepted for inclusion in Institute for Immunology and Informatics Faculty Publications by an authorized administrator of DigitalCommons@URI. For more information, please contact digitalcommons-group@uri.edu. 


\section{Authors}

Sasmita Mishra, Phyllis T. Losikoff, Alyssa A. Self, Frances Terry, Matthew T. Ardito, Ryan Tassone, William D. Martin, Anne S. De Groot, and Stephen H. Gregory 


\section{Peptide-pulsed Dendritic Cells Induce the Hepatitis C Viral} Epitope-specific Responses of Naïve Human T Cells

21 Corresponding author: Dr. Stephen H. Gregory, Department of Medicine, Rhode Island Hospital 22 and The Warren Alpert Medical School of Brown University, 432 Pierre M. Galletti Building, 55

23 Claverick Street, Providence, RI 02903. Telephone: 401-444-7369; FAX: 401-444-7524; Email:

24 sgregory@lifespan.org

Sasmita Mishra, ${ }^{1}$ Phyllis T. Losikoff, ${ }^{1}$ Alyssa A. Self, ${ }^{1}$ Frances Terry, ${ }^{2}$ Matthew T. Ardito, ${ }^{2}$ Ryan Tassone, ${ }^{2}$ William D. Martin, ${ }^{2}$ Anne S. De Groot ${ }^{2,3}$ and Stephen H. Gregory ${ }^{1}$

${ }^{1}$ Department of Medicine, Rhode Island Hospital and the Warren Alpert Medical School of Brown University, Providence, RI; ${ }^{2}$ EpiVax, Inc., Providence, RI; and ${ }^{3}$ Institute for Immunology and Informatics, University of Rhode Island, Providence, RI Abbreviations: DCs, dendritic cells; HCV, hepatitis C virus; ICS, immunogenic consensus sequences; NS, nonstructural; PBMC, peripheral blood mononuclear cell; SVR, sustained virologic response

\section{8} 19 
Hepatitis $\mathrm{C}$ virus $(\mathrm{HCV})$ is a major cause of liver disease. Spontaneous resolution of infection is

27 associated with broad, $\mathrm{MHC}$ class I- $\left(\mathrm{CD}^{+}\right)$and class II-restricted $\left(\mathrm{CD} 4^{+}\right) \mathrm{T}$ cell responses to

28 multiple viral epitopes. Only $20 \%$ of patients clear infection spontaneously, however, most develop

29 chronic disease. The response to chemotherapy varies; therapeutic vaccination offers an additional

30 treatment strategy. To date, therapeutic vaccines have demonstrated only limited success in clinical

31 trials. Vector-mediated vaccination with multi-epitope-expressing DNA constructs provides an

32 improved approach. Highly-conserved, HLA-A2-restricted HCV epitopes and HLA-DRB1-restricted immunogenic consensus sequences (ICS, each composed of multiple overlapping and highly conserved epitopes) were predicted using bioinformatics tools and synthesized as peptides. HLA binding activity was determined in competitive binding assays. Immunogenicity and the ability of each peptide to stimulate naïve human T cell recognition and IFN-Y production were assessed in

37 cultures of total PBMCs and in co-cultures composed of peptide-pulsed dendritic cells (DCs) and purified T lymphocytes, cell populations derived from normal blood donors. Essentially all predicted HLA-A2-restricted epitopes and HLA-DRB1-restricted ICS exhibited HLA binding activity and the ability to elicit immune recognition and IFN-y production by naïve human T cells. The ability of DCs

41 pulsed with these highly-conserved HLA-A2- and-DRB1-restricted peptides to induce naïve human

42 T cell reactivity and IFN-y production ex vivo demonstrates the potential efficacy of a multi-epitope43 based HCV vaccine targeted to dendritic cells.

Keywords. dendritic cell; EpiMatrix; epitope; HCV; vaccine; T cell 
47 Hepatitis $\mathrm{C}$ virus (HCV), a small single-stranded RNA virus, constitutes a major cause of liver

48 disease [1]. The positive-sense genome encodes an 3,000 amino acid poly-protein precursor,

49 which is cleaved by cellular and viral proteases to yield three structural [core, envelope $1(E 1)$ and

50 E2], and seven nonstructural (p7, NS2, NS3, NS4a, NS4b, NS5a and NS5b) proteins [2].

51 Spontaneous resolution of HCV infections is associated with broad, MHC class I- (CD8 $\left.{ }^{+}\right)$and class

52 II-restricted $\left(\mathrm{CD4}^{+}\right) \mathrm{T}$ cell responses to multiple viral epitopes derived from these proteins $[3,4]$.

53 Unfortunately, only $20 \%$ of patients clear infection spontaneously, most develop chronic disease [5].

54 Seventy to eighty percent of patients infected with HCV genotype 1 (the principal causative agent of

55 hepatitis $\mathrm{C}$ in the U.S.) experience a sustained virologic response (SVR) following treatment that

56 includes protease inhibitors, i.e., telaprevir or boceprevir, administered in conjunction with

57 PEGylated interferon and ribavirin. A significant number of those treated remains infected, however,

58 the cost of treatment is high, and the risk and severity of side effects are considerable [6,7]. New

59 approaches to treating chronic HCV infections are urgently needed.

Therapeutic vaccination concurrent with or without drug therapy offers an additional approach

to treating chronic hepatitis C. Indeed, the capacity of a significant percentage of patients to resolve

62 acute infections spontaneously suggests that an effective therapeutic vaccine is a realistic goal. A

63 safe and effective vaccine must elicit broad, vigorous $\mathrm{CD} 4^{+}$and $\mathrm{CD}^{+} \mathrm{T}$ cells responses to

64 conserved viral epitopes, which culminate in the elimination of HCV without causing liver pathology.

65 Development of such a vaccine has proven problematic, however, due primarily to: infidelity of the

66 viral RNA polymerase (NS5b), genetic diversity and the rapid emergence of viral variants [8]. To

67 date, a number of vaccine strategies have demonstrated negligible or only limited success in clinical 68 trials $[9,10]$.

69 Vaccination with HCV epitope expressing dendritic cells (DCs) offers a vector-mediated approach to treating chronic, $\mathrm{HCV}$ infected patients. DCs play a central role in $\mathrm{CD}^{+}$and $\mathrm{CD}^{+} \mathrm{T}$ cell 
71 activation and the induction of immunity [11]. The potential effectiveness of DC-based vaccines in

72 treating chronic hepatitis $C$ has been demonstrated in animal models [12-14]. Moreover, in a recent

73 Phase I clinical trial, chronically-infected patients vaccinated with monocyte-derived DCs pulsed with

746 HCV-specific, HLA-class I-restricted peptides exhibited peptide-specific CD8 T cell responses [15].

75 These responses were not sustained, however, and there was no effect on viral load suggesting that

$76 \mathrm{HCV}$ clearance might require vaccination with DCs that expressed a broader range of viral epitopes.

77 Toward this end, immunoinformatics tools were used to predict 21 HLA-A*0201-restricted epitopes

78 and 19 HLA-DRB1-restricted immunogenic consensus sequences (ICS, each composed of multiple

79 epitopes), which were highly-conserved and encoded by HCV genotype 1. These predicted

80 epitopes/ICS were synthesized as peptides and their capacities to bind HLA molecules were

81 determined. Subsequently, their immunogenicity and ability to elicit the peptide-specific responses of

82 naïve human T cells were validated in an in vitro peripheral blood mononuclear cell (PBMC)

83 immunogenicity assay. Similarly, monocyte-derived DCs pulsed with these same peptides induced

84 the epitope-specific responses of naïve $\mathrm{CD} 4^{+}$and $\mathrm{CD} 8^{+} \mathrm{T}$ cells in culture demonstrating the potential 85 efficacy of a multi-epitope-based HCV vaccine that targets dendritic cells.

86

87

88 
Genome Collection

Hepatitis $C$ viral sequences marked complete, representing a total of 871 genotype 1 a and genotype 1b polyproteins, were acquired from the Los Alamos sequence and immunology database $[16,17]$.

\section{Conserved 9-mer search}

93 Nine-mer amino acid sequences, constituting the length of the peptide chain that fits into the binding groove of the HLA class I and class II molecules, were parsed out of the polyproteins and compared using the Conservatrix algorithm [18]. The potential immunogenicity of these identical 9-mer sequences was predicted using the computational method described below.

\section{Epitope mapping}

Approximately $50 \%$ of the population residing in the U.S. expresses cell-surface HLA-A2; essentially the entire population expresses one or more HLA-DRB1 alleles [19,20]. Consequently, each 9-mer was scored for its predicted potential to bind a panel of eight HLA-DRB1 alleles (DRB1*0101, $\mathrm{DRB} 1{ }^{*} 0301, \mathrm{DRB} 1{ }^{*} 0401, \mathrm{DRB} 1{ }^{*} 0701, \mathrm{DRB} 1{ }^{*} 0801, \mathrm{DRB} 1{ }^{*} 1101, \mathrm{DRB} 1{ }^{*} 1301$ and $\left.\mathrm{DRB} 1{ }^{*} 1501\right)$ using EpiMatrix, a matrix-based algorithm for mapping T cell epitopes [21,22]. Additionally, all parsed 9-mers were scored for the potential to bind HLA-A2. Putative HLA-A2 epitopes were selected based on conservation in genotype 1a and b, EpiMatrix HLA A2-matrix predicted binding score, and reports of the ex vivo response of PBMCs obtained from HCV-infected patients.

\section{Immunogenic consensus sequences}

108 HLA-DRB1-restricted ICS were constructed using EpiAssembler, an algorithm that maximizes 109 epitope density by assembling potentially immunogenic 9-mers (identified using EpiMatrix) into 1825 amino acid stretches [23]. To avoid potential cross-reactivity with the human proteome, any peptide that shared more than 7 identities per 9-mer frame was eliminated from further consideration 
112 [24]. The final HLA-A2- and -DRB1-restricted peptide sequences were synthesized using 9-

113 fluoronylmethoxycarbonyl chemistry and purified $>85 \%$ by $21^{\text {st }}$ Century Biochemicals

114 (Marlboro, MA).

\section{HLA Binding Assay}

116 The capacity of predicted epitopes (peptides) to bind multiple HLA-DRB1 alleles was assessed

117 using a competitive, HLA class II binding assay as we described previously [24,25], using HLA

118 molecules obtained from Bill Kwok, Benaroya Research Institute, Seattle, WA). Assays were

119 performed for HLA-DRB1*0101, -DRB1*0301, -DRB1*0401, -DRB1*0701, -DRB1*1101 and -

120 DRB1*1501, alleles that provide broad representation of HLA class II that are prevalent in human

121 populations [20]. $I_{50}$ values were estimated and the predicted peptides were classified as exhibiting

122 very high $(<1 \mu \mathrm{M})$, high $(1 \mu \mathrm{M}-10 \mu \mathrm{M})$, moderate $(10 \mu \mathrm{M}-100 \mu \mathrm{M})$ or low $(>100 \mu \mathrm{M})$ affinity.

123 Peptides that exhibited very high, high or moderate affinity were considered binders (a more detailed

124 classification is provided in the results section).

125 The ability of predicted epitopes to bind HLA-A*0201 was assessed using a fluorescence

126 polarization-based competitive peptide-binding assay according to published methods [26]. The

127 concentration of experimental peptide that inhibited $50 \%$ binding of the FITC-labeled reference

128 peptide $\left(\mathrm{IC}_{50}\right)$ was determined. Experimental peptides were considered: high $\left(\mathrm{IC}_{50}<5 \mu \mathrm{M}\right)$, moderate $129\left(5 \mu \mathrm{M}<\mathrm{IC}_{50}<50 \mu \mathrm{M}\right)$ and low $\left(\mathrm{IC}_{50}=50-100 \mu \mathrm{M}\right)$ affinity binders. Peptides that failed to demonstrate 130 dose-dependent inhibition or exhibited an $\mathrm{IC}_{50}>100 \mu \mathrm{M}$ were considered non-binders.

\section{Human subjects}

132 Whole-blood leukocyte reduction filters (blood filters; Sepacell RZ-2000, Baxter Healthcare

133 Corporation, Irvine CA) were obtained from the Rhode Island Blood Center (Providence, RI). These 134 used, de-identified filters contain white cells derived from blood donated with informed consent by 
healthy volunteers. The Lifespan Institutional Review Board (Rhode Island Hospital) approved this study.

\section{Peripheral blood mononuclear cell (PBMC) recovery and purification}

PBMCs were recovered from blood filters according to the methods of Meyer et al. [27]. Filters obtained within a 4-hour period following the leukocyte depletion step were back-flushed at room temperature with Ca- and Mg-free Hank's basic salt solution containing sodium-EDTA and sucrose. The recovered leucocytes were purified by centrifugation on Ficoll-Paque Plus (1.077; Pharmacia, Uppsala, Sweden) gradient. All donors expressed HLA-A*0201 and HLA-DRB1.

\section{Naïve PBMC cultures}

The peptide-specific responses of naïve human T cells were induced by culturing purified PBMCs under conditions described by others and modified in our laboratory [28]. PBMCs, $2.5 \times 10^{5} / 200 \mu \mathrm{l}$ serum-free X-VIVO 15 medium (Lonza, Walkerville, MD) supplemented with glutamine, penicillin, streptomycin, and $50 \mathrm{U} / \mathrm{ml}$ recombinant human IL-2 (Roche Applied Science, Indianapolis, IN), were transferred to 96 -well round bottom tissue culture plates and incubated 14 days with single (10 $\mu \mathrm{g} / \mathrm{ml}$ ) HLA-A2- or -DRB1-restricted peptide. Half the spent medium was replaced with fresh medium containing IL-2, but no additional peptide, on days 3, 7 and 10 of the incubation period.

\section{ELISpot assays}

Cells collected after 14 days incubation under the culture conditions described were washed and resuspended in X-VIVO 15 medium supplemented with glutamine and antibiotics. The frequency of epitope-specific T lymphocytes was quantified using human IFN-y ELISpot assay kits purchased from eBioscience, Inc. (San Diego, CA) and the protocol provided. Triplicate wells were inoculated with 50,000 cells $/ 200 \mu \mathrm{I}$ X-VIVO 15 medium and $10 \mu \mathrm{g} / \mathrm{ml}$ of the same peptide present during the pre-stimulation period. Positive (phytohemagglutinin) and negative ( $0.1 \% \mathrm{DMSO})$ controls were included. 


\section{DC priming of naïve T cell ex vivo}

160 Monocyte-derived DCs were generated in vitro in accordance with methods described by others

161 [29]. CD14 ${ }^{+}$monocytes were purified from PBMCs back-flushed from blood filters using anti-CD14-

162 coated magnetic beads (Miltenyi Biotec; Auburn, CA). T lymphocytes were purified by negative

163 selection using the human pan T cell isolation kit II also purchased from Miltenyi. Biotin-conjugated

164 anti-mouse CD25 (Miltenyi) was added to the biotin-conjugated antibody cocktail supplied with the

165 kit to eliminate $\mathrm{CD}_{25} 5^{+}$regulatory T cells. Purified T lymphocytes were frozen and stored in liquid

166 nitrogen for later use. The purified CD14+ monocytes were suspended in X-VIVO 15 medium that

167 contained L-glutamine, penicillin, streptomycin, 100 ng/ml GM-CSF (PreproTech, Rocky Hill, NJ)

168 and 25 ng/nl IL-4 (PeproTech), and cultured in 24-well, ultra-low attachment tissue culture plates

169 (Corning Inc., Lowell, MA). Half the medium was replenished with fresh medium containing GM-CSF

170 and IL-4 on day 3. The resultant DC population was collected on day 5; the cells were suspended in

171 fresh X-VIVO medium, transferred to individual wells of a 96 -well, round bottom plate $\left(1 \times 10^{4}\right.$

172 cells $/ 200 \mu \mathrm{l}$ medium) and pulsed with single $(10 \mu \mathrm{g} / \mathrm{ml})$ peptides. On the following day, $25 \mathrm{ng} / \mathrm{ml}$

173 TNF- $\alpha$ (PeproTech) was added to promote DC maturation. After another 48 hours incubation, $100 \mu$ l

174 of medium was removed, $6 \times 10^{5}$ naïve T lymphocytes (derived from the population purified and

175 frozen above)/100 $\mu$ I X-VIVO medium were added to each well; and the cells were co-cultured.

176 To quantify the epitope-specific responses of purified T cells co-cultured with peptide-pulsed

177 DCs, the cells were collected after 14 days incubation, centrifuged and resuspended in fresh X-VIVO

17815 medium. The cells $(50,000 / 100 \mu l)$ were transferred to IFN- $\gamma$ capture antibody-coated ELISpot

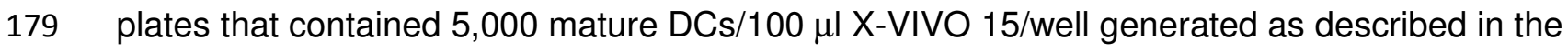

180 previous section and pulsed with the same peptide present during the initial co-culture period. The

181 remainder of the assay was conducted according to the supplier's protocol referenced in the

182 preceding section. 


\section{Epitope/ICS predictions}

A set of $21, \mathrm{HLA}-\mathrm{A}^{*} 0201-$-restricted epitopes were selected for synthesis from a set of more than 100 highly conserved, high-scoring peptides predicted using the EpiMatrix and Conservatrix algorithms (Table I). Twenty of these epitopes scored in the top $1 \%$ (Z score $\geq 2.32$ ) and one (peptide ID\# 13) scored in the top $5 \%$ (Z score $\geq 1.64)$ of predicted binders, indicating a very high probability of HLA$A^{*} 0201$ binding. The amino acid sequence, $A^{*} 0201$ EpiMatrix Z Scores and relative conservation of these peptides among HCV genotypes $1 \mathrm{a}$ and $1 \mathrm{~b}$ isolates (calculated using Conservatrix) are shown in Table II.

Twenty-five HLA-DRB1-restricted ICS from the input HCV genotype $1 \mathrm{a}$ and $1 \mathrm{~b}$ sequences were selected from a list of 79 that were predicted using the EpiAssembler algorithm; these varied from 15 to 27 amino acids in length. Each was composed of multiple, overlapping 9-mers (epitopes) capable of binding more than one HLA-DRB1 allele. The number of epitopes contained within each ICS predicted to bind across all 8 alleles was determined and ranged from 5 to 28 epitopes/ICS. Among the original 25 ICS, three exhibited significant homology to sequences found in the human genome and three overlapped protein junctions located within the HCV poly-protein; these six ICS were excluded from further study. The amino acid sequence, HLA-DRB1 EpiMatrix Z scores, number of predicted epitopes and conservation of the 19 remaining ICS among HCV genotypes 1a and $1 \mathrm{~b}$ isolates are shown in Table II.

\section{Binding analyses}

Each predicted epitope/ICS was synthesized. HLA binding affinity and concurrence with computational predictions were determined. Positive predictions were defined as epitope scores

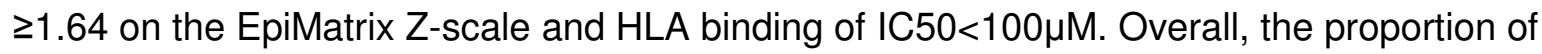
predictions that concurred with binding was $~ 90 \%(19 / 21)$ and $84 \%(96 / 114)$ for the HLA-A*0201- 
restricted peptides (Table III) and HLA-DRB1-restricted ICS (Table IV), respectively. We expect no

209 more than three to five percent of randomly selected peptides to bind to any given HLA. In the

210 current case, approximately $85 \%$ of all predictions were confirmed, consistent with our previous

211 experience. The small number of negative predictions present in this dataset makes statistical

212 validation of the correlation between predicted binding and observed results difficult. We suggest

213 that the correlation between prediction and observed outcome is self-evident.

\section{Epitope/ICS validation.}

215 All predicted A2-restricted epitopes and DRB1-restricted ICS that exhibited HLA binding affinity

216 induced naïve T cell reactivity and IFN-y production ex vivo, validating their immunogenicity.

217 PBMCs obtained from healthy blood donors and cultured 14 days in the presence of single peptides

218 subsequently exhibited peptide-specific IFN-y production in ELISpot assays (Figure 1). Similar

219 results were obtained when purified, naïve human T lymphocytes were co-cultured with CD14

220 monocyte-derived DCs pulsed with peptides. DCs pulsed with single HLA-A2-restricted or -DRB1-

221 restricted peptides induced marked increases in IFN-y production by naïve human T cells in ELISpot

222 assays (Figure 2). Notably, all peptide sequences induced IFN-ץ production, but not to the same

223 extent in co-cultures derived from different blood donors.

224

225

226 


\section{Discussion}

227 Triple drug therapy (telaprevir or boceprevir, combined with PEGylated interferon and ribavirin) is

228 recommended by the American Association for the Study of Liver Diseases as the standard

229 treatment for unresolved HCV genotype 1 infections [30]. The SVR rate is improved significantly in

230 patients who receive triple therapy compared to those treated with PEGylated interferon and ribavirin

231 alone. While the outcome is improved, the overall success of triple drug therapy is limited by a

232 variety of factors that include: general access to health care, cost of therapy, patient compliance,

233 drug-drug interactions, emergence of anti-viral resistant variants, adverse side effects, and host

234 factors that affect relative effectiveness [30,31]. Indeed, logistics and expense are major deterrents

235 in treating chronically infected patients with antiviral drugs worldwide. As such, the development of a

236 safe, effective and affordable vaccine represents the best hope for bringing the global hepatitis $\mathrm{C}$

237 epidemic under control, a stated objective in the US Department of Health and Human Services'

238 Viral Hepatitis Action plan [32].

A safe and effective therapeutic vaccine for chronic hepatitis $\mathrm{C}$ must elicit broad, vigorous

$\mathrm{CD}^{+}$and $\mathrm{CD}^{+} \mathrm{T}$ cell responses to conserved viral epitopes, which result in viral elimination in the absence of significant liver injury. To date, four distinct vaccine strategies have demonstrated only

242 limited success in clinical trials: recombinant protein, peptide, genetic or DNA-based and vector-

243 mediated $[9,10,33]$. Recombinant protein vaccines are safe and well tolerated, but generally

244 ineffective owing to their inability to induce a CD8 ${ }^{+} \mathrm{T}$ cells. Peptide-based HCV vaccines are similarly

245 ineffective despite their ability to elicit weak, epitope-specific T cell responses; only a transient

246 reduction in viral load was determined in a minority of chronically-infected patients [34,35]. Similarly,

247 patients vaccinated with a codon-optimized HCV NS3/4A DNA construct exhibited only a transient

248 reduction in serum viral load [36]. Finally, just half of the chronically-infected patients vaccinated in a

249 Phase I clinical trial with modified vaccinia virus Ankara [MVA] engineered to express HCV NS3-5B

250 proteins exhibited a temporary reduction in viral load [37]. 
Therapeutic vaccination with HCV epitope-expressing DCs concurrent with or without

chemotherapy offers an additional vector-mediated approach to treating chronic, HCV-infected patients. The utility of this approach is supported by clinical trials demonstrating tumor regression and long-term survival in a subset of cancer patients administered antigen-pulsed DCs [38]. Indeed, FDA approval of Dendreon's prostate cancer vaccine, Sipuleucel-T (Provenge), demonstrates the feasibility of developing a DC-vectored therapeutic vaccine for chronic hepatitis. The potential efficacy of DC-based vaccines in treating chronic hepatitis $C$ was demonstrated in a recent Phase I clinical trial in which patients vaccinated with monocyte-derived DCs pulsed with 6 HCV-specific, HLA-class I-restricted peptides exhibited peptide-specific CD8 T cell responses [15]. These responses were not sustained, however, nor was an effect on viral load discerned. The failed response of patients vaccinated with peptide-pulsed DCs in this clinical trial was attributed to the dearth of viral epitopes presented [15]. Immunization with DCs that express a broad array of HLA class I- and class II-restricted viral epitopes offers a means of significantly enhancing vaccine efficacy.

The data presented herein support the EpiMatrix algorithm as an approach to high-volume genomic screening for vaccine candidates. Nineteen of 21 predicted, HLA class I-restricted peptides (>90\%) were bound by HLA A*0201 in vitro, in accordance with previously published data [39]. All predicted HLA-class II-restricted peptides were bound by at least three HLA-DRB1 alleles, substantiating their promiscuity and potential recognition by a large, diverse human population [20]. A large, retrospective comparison conducted previously found EpiMatrix was $>75 \%$ accurate across the HLA-DRB1 alleles studied here, and more accurate than all other epitope mapping algorithms in the public domain [22]. In the present study, 96 of the 114 HLA-DRB1-peptide pairs exhibited binding as predicted. Conceivably, a number of factors (e.g., peptide folding or aggregation under assay conditions, and the accuracy of immunoinformatic algorithms) contribute to the lack of a strict correlation between predicted and actual binding. 


\section{Conclusion}

278 IFN- $\gamma$ is a principal mediator of anti-HCV-specific T cell responses $[40,41]$. All the predicted, HLA-

279 A2-restricted and -DRB1-restricted peptides that exhibited HLA binding activity also induced IFN- $\gamma$

280 production in cultures of naïve human PBMCs, thus validating their immunogenicity and the

281 prognostic accuracy of the EpiMatrix algorithm. Similarly, monocyte-derived DCs pulsed with the

282 same peptides and co-cultured with naïve CD4 ${ }^{+}$and CD8 ${ }^{+}$human T cells induced epitope-specific

283 IFN-y production. This latter observation supports the therapeutic potential of DCs pulsed ex vivo

284 with a broad array of HLA-A2- and -DRB1-restricted epitopes in treating chronic, HCV-infected

285 patients. This approach suffers, however, from a number of practical limitations, foremost of which is

286 the estimated high cost of treatment. Instead, we are currently exploring alternative strategies that

287 include delivering the epitopes validated herein to DCs in situ. Regardless, epitope-driven

288 immunotherapy alone or in combination with chemotherapy offers an additional means of treating

289 the expanding patient population affected by chronic hepatitis C. 


\section{Acknowledgements}

293 Supported by National Institutes of Health Research Grant U19 Al082642.

294

295 Authors' contributions

296 SM, PTL and SHG: experimental design and performance, data analyses, manuscript preparation;

297 AS and RT: experimental performance and data acquisition; FT, MA, WM and ADG: EpiMatrix

298 analysis, interpretation and discussion. All authors have read and approve of this article.

299

300 Disclosures

301 Anne De Groot and William Martin are senior officers and majority shareholders at EpiVax, Inc.

302 These authors acknowledge a potential conflict of interest and attest that the work contained in this

303 report is free of any bias that might be associated with the commercial goals of the company. None

304 of the remaining co-authors has any potential financial conflict of interest related to the manuscript to 305 disclose.

306 


\section{References}

307

308

[1] D. Moradpour, F. Penin, C.M. Rice, Replication of hepatitis C virus, Nat. Rev. Microbiol. 5 (2007) 453-463 .

[2] A. Grakoui, C. Wychowski, C. Lin, S.M. Feinstone, C.M. Rice, Expression and identification of hepatitis C virus polyprotein cleavage products, J. Virol. 67 (1993) 1385-1395 .

[3] G. Missale, R. Bertoni, V. Lamonaca, A. Valli, M. Massari, C. Mori, M.G. Rumi, M. Houghton, F. Fiaccadori, C. Ferrari, Different clinical behaviors of acute hepatitis C virus infection are associated with different vigor of the anti-viral cell-mediated immune response, J. Clin. Invest 98 (1996) 706-714 .

[4] F. Lechner, D.K. Wong, P.R. Dunbar, R. Chapman, R.T. Chung, P. Dohrenwend, G. Robbins, R. Phillips, P. Klenerman, B.D. Walker, Analysis of successful immune responses in persons infected with hepatitis C virus, J. Exp. Med. 191 (2000) 1499-1512.

[5] H.B. El Serag, Hepatocellular carcinoma and hepatitis C in the United States, Hepatology 36 (2002) S74-S83 .

[6] E.A. Schaefer and R.T. Chung, Anti-hepatitis C virus drugs in development, Gastroenterology 142 (2012) 1340-1350.

[7] U.S.Food and Drug Administration, Incivek (telaprevir) in combination with drugs peginterferon alfa and ribavirin (incivek combination treatment): drug safety communication - serious skin reactions, Electronic Communication, USDA Website (2012) .

[8] P. Simmonds, Genetic diversity and evolution of hepatitis C virus--15 years on, J. Gen. Virol. 85 (2004) 3173-3188 .

[9] C.I. Yu and B.L. Chiang, A new insight into hepatitis C vaccine development, J. Biomed. Biotechnol. 2010 (2010) 548280 .

[10] J. Halliday, P. Klenerman, E. Barnes, Vaccination for hepatitis C virus: closing in on an evasive target, Expert. Rev. Vaccines. 10 (2011) 659-672 . 
[11] J. Banchereau and R.M. Steinman, Dendritic cells and the control of immunity, Nature 392 (1998) 245-252 .

[12] J. Encke, J. Findeklee, J. Geib, E. Pfaff, W. Stremmel, Prophylactic and therapeutic vaccination with dendritic cells against hepatitis C virus infection, Clin. Exp. Immunol. 142 (2005) 362-369 .

[13] N. Kuzushita, S.H. Gregory, N.A. Monti, R. Carlson, S. Gehring, J.R. Wands, Vaccination with protein-transduced dendritic cells elicits a sustained response to hepatitis $\mathrm{C}$ viral antigens, Gastroenterology 130 (2006) 453-464 .

[14] K. Weigand, F. Voigt, J. Encke, B. Hoyler, W. Stremmel, C. Eisenbach, Vaccination with dendritic cells pulsed with hepatitis $C$ pseudo particles induces specific immune responses in mice, World J. Gastroenterol. 18 (2012) 785-793 .

[15] E.J. Gowans, S. Roberts, K. Jones, I. Dinatale, P.A. Latour, B. Chua, E.M. Eriksson, R. Chin, S. Li, D.M. Wall, R.L. Sparrow, J. Moloney, M. Loudovaris, R. Ffrench, H.M. Prince, D. Hart, W. Zeng, J. Torresi, L.E. Brown, D.C. Jackson, A phase I clinical trial of dendritic cell immunotherapy in HCV-infected individuals, J. Hepatol. 53 (2010) 599-607 .

[16] C. Kuiken, K. Yusim, L. Boykin, R. Richardson, The Los Alamos hepatitis C sequence database, Bioinformatics. 21 (2005) 379-384 .

[17] K. Yusim, R. Richardson, N. Tao, A. Dalwani, A. Agrawal, J. Szinger, R. Funkhouser, B. Korber, C. Kuiken, Los Alamos hepatitis C immunology database, Appl. Bioinformatics. 4 (2005) 217-225 .

[18] J.R. Schafer, B.M. Jesdale, J.A. George, N.M. Kouttab, A.S. De Groot, Prediction of wellconserved HIV-1 ligands using a matrix-based algorithm, EpiMatrix, Vaccine 16 (1998) 18801884 .

[19] J.M. Ellis, V. Henson, R. Slack, J. Ng, R.J. Hartzman, H.C. Katovich, Frequencies of HLA-A2 alleles in five U.S. population groups. Predominance Of $A^{*} 02011$ and identification of HLAA*0231, Hum. Immunol. 61 (2000) 334-340 . 
[20] S. Southwood, J. Sidney, A. Kondo, M.F. del Guercio, E. Appella, S. Hoffman, R.T. Kubo, R.W. Chesnut, H.M. Grey, A. Sette, Several common HLA-DR types share largely overlapping peptide binding repertoires, J. Immunol. 160 (1998) 3363-3373 .

[21] A.S. De Groot, B.M. Jesdale, E. Szu, J.R. Schafer, R.M. Chicz, G. Deocampo, An interactive Web site providing major histocompatibility ligand predictions: application to HIV research, AIDS Res. Hum. Retroviruses 13 (1997) 529-531.

[22] A.S. De Groot and W. Martin, Reducing risk, improving outcomes: bioengineering less immunogenic protein therapeutics, Clin. Immunol. 131 (2009) 189-201.

[23] A.S. De Groot, E.A. Bishop, B. Khan, M. Lally, L. Marcon, J. Franco, K.H. Mayer, C.C. Carpenter, W. Martin, Engineering immunogenic consensus T helper epitopes for a crossclade HIV vaccine, Methods 34 (2004) 476-487 .

[24] M. Ardito, J. Fueyo, R. Tassone, F. Terry, K. DaSilva, S. Zhang, W. Martin, A.S. De Groot, S.F. Moss, L. Moise, An integrated genomic and immunoinformatic approach to $H$. pylori vaccine design, Immunome. Res. 7 (2011) 1.

[25] J.A. McMurry, S.H. Gregory, L. Moise, D. Rivera, S. Buus, A.S. De Groot, Diversity of Francisella tularensis Schu4 antigens recognized by T lymphocytes after natural infections in humans: Identification of candidate epitopes for inclusion in a rationally designed tularemia vaccine, Vaccine 25 (2007) 3179-3191.

[26] R. Buchli, R.S. VanGundy, H.D. Hickman-Miller, C.F. Giberson, W. Bardet, W.H. Hildebrand, Development and validation of a fluorescence polarization-based competitive peptide-binding assay for HLA-A*0201--a new tool for epitope discovery, Biochemistry 44 (2005) 12491-12507

[27] T.P. Meyer, I. Zehnter, B. Hofmann, J. Zaisserer, J. Burkhart, S. Rapp, F. Weinauer, J. Schmitz, W.E. Illert, Filter Buffy Coats (FBC): a source of peripheral blood leukocytes recovered from leukocyte depletion filters, J. Immunol. Methods 307 (2005) 150-166 . 
[28] D. Wullner, L. Zhou, E. Bramhall, A. Kuck, T.J. Goletz, S. Swanson, N. Chirmule, V. Jawa, Considerations for optimization and validation of an in vitro PBMC derived T cell assay for immunogenicity prediction of biotherapeutics, Clin. Immunol. 137 (2010) 5-14 .

[29] J.M. Moser, E.R. Sassano, d.C. Leistritz, J.M. Eatrides, S. Phogat, W. Koff, D.R. Drake, III, Optimization of a dendritic cell-based assay for the in vitro priming of naive human $\mathrm{CD} 4^{+} \mathrm{T}$ cells , J. Immunol. Methods 353 (2010) 8-19.

[30] M.G. Ghany, D.R. Nelson, D.B. Strader, D.L. Thomas, L.B. Seeff, An update on treatment of genotype 1 chronic hepatitis $\mathrm{C}$ virus infection: 2011 practice guideline by the American Association for the Study of Liver Diseases, Hepatology 54 (2011) 1433-1444 .

[31] A. Tungol, K. Rademacher, J.A. Schafer, Formulary management of the protease inhibitors boceprevir and telaprevir for chronic hepatitis C virus, J. Manag. Care Pharm. 17 (2011) 685694 .

[32] Department of Health and Human Services, Combating the silent epidemic of viral hepatitis: action plan for the prevention, care \& treatment of viral hepatitis, Available at: http://www. hhs. gov/ash/initiatives/hepatitis/actionplan_viralhepatitis2011. pdf (2011) .

[33] G.M. Lauer, Immune responses to hepatitis C virus (HCV) infection and the prospects for an effective HCV vaccine or immunotherapies, J. Infect. Dis. 207 Suppl 1 (2013) S7-S12 .

[34] C.S. Klade, H. Wedemeyer, T. Berg, H. Hinrichsen, G. Cholewinska, S. Zeuzem, H. Blum, M. Buschle, S. Jelovcan, V. Buerger, E. Tauber, J. Frisch, M.P. Manns, Therapeutic vaccination of chronic hepatitis C nonresponder patients with the peptide vaccine IC41, Gastroenterology 134 (2008) 1385-1395 .

[35] S. Yutani, A. Yamada, K. Yoshida, Y. Takao, M. Tamura, N. Komatsu, T. Ide, M. Tanaka, M. Sata, K. Itoh, Phase I clinical study of a personalized peptide vaccination for patients infected with hepatitis $\mathrm{C}$ virus (HCV) 1b who failed to respond to interferon-based therapy, Vaccine 25 (2007) 7429-7435 . 
[36] O. Weiland, G. Ahlen, H. Diepolder, M.C. Jung, S. Levander, M. Fons, I. Mathiesen, N.Y. Sardesai, A. Vahlne, L. Frelin, M. Sallberg, Therapeutic DNA vaccination using in vivo electroporation followed by standard of care therapy in patients with genotype 1 chronic hepatitis C, Mol. Ther. 21 (2013) 1796-1805.

[37] F. Habersetzer, G. Honnet, C. Bain, M. Maynard-Muet, V. Leroy, J.P. Zarski, C. Feray, T.F. Baumert, J.P. Bronowicki, M. Doffoel, C. Trepo, D. Agathon, M.L. Toh, M. Baudin, J.Y. Bonnefoy, J.M. Limacher, G. Inchauspe, A poxvirus vaccine is safe, induces T-cell responses, and decreases viral load in patients with chronic hepatitis C, Gastroenterology 141 (2011) 890899.

[38] K. Palucka and J. Banchereau, Cancer immunotherapy via dendritic cells, Nat. Rev. Cancer 12 (2012) 265-277 .

[39] L. Levitz, O.A. Koita, K. Sangare, M.T. Ardito, C.M. Boyle, J. Rozehnal, K. Tounkara, S.M. Dao, Y. Kone, Z. Koty, S. Buus, L. Moise, W.D. Martin, A.S. De Groot, Conservation of HIV-1 T cell epitopes across time and clades: validation of immunogenic HLA-A2 epitopes selected for the GAIA HIV vaccine, Vaccine 30 (2012) 7547-7560 .

[40] P. Metz, E. Dazert, A. Ruggieri, J. Mazur, L. Kaderali, A. Kaul, U. Zeuge, M.P. Windisch, M. Trippler, V. Lohmann, M. Binder, M. Frese, R. Bartenschlager, Identification of type I and type II interferon-induced effectors controlling hepatitis C virus replication, Hepatology 56 (2012) 2082-2093 .

[41] J. Jo, U. Aichele, N. Kersting, R. Klein, P. Aichele, E. Bisse, A.K. Sewell, H.E. Blum, R. Bartenschlager, V. Lohmann, R. Thimme, Analysis of CD8 ${ }^{+}$T-cell-mediated inhibition of hepatitis C virus replication using a novel immunological model, Gastroenterology 136 (2009) 1391-1401 . 
Table I. Predicted, HLA-A*0201-restricted HCV epitopes

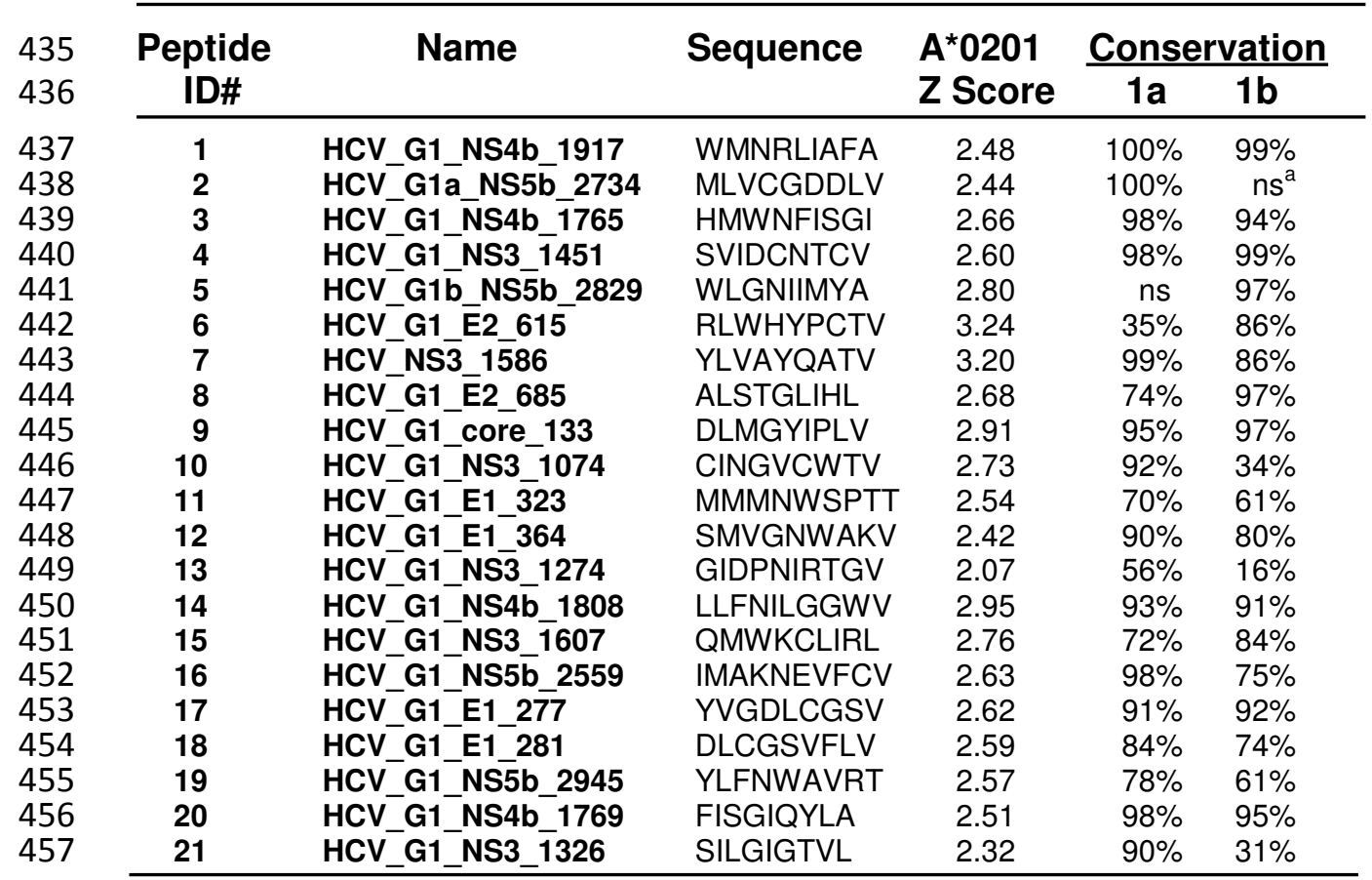

$458 \quad{ }^{a} \mathrm{~ns}=$ not significant. 
459 Table II. Predicted, HLA-DRB1-restricted HCV ICS

\begin{tabular}{|c|c|c|c|c|c|c|c|c|}
\hline \multirow{2}{*}{$\begin{array}{l}400 \\
461 \\
462\end{array}$} & \multirow{2}{*}{\multicolumn{2}{|c|}{$\begin{array}{c}\text { Peptide } \\
\text { ID\# }\end{array}$}} & \multirow[t]{2}{*}{ Name } & \multirow[t]{2}{*}{ Sequence } & \multirow{2}{*}{$\begin{array}{c}\text { DRB1*0101 } \\
\text { Z Score }\end{array}$} & \multirow{2}{*}{$\begin{array}{c}\text { Predicted \# } \\
\text { Epitopes } \\
\end{array}$} & \multicolumn{2}{|c|}{ Conservation } \\
\hline & & & & & & & $1 \mathrm{a}$ & $1 b$ \\
\hline 463 & 1 & $\mathrm{HCV}$ & _G1_NS3_1246 & AQGYKVLVLNPSVAATLGFG & 2.15 & 20 & $>90 \%$ & $>90 \%$ \\
\hline 464 & 2 & $\mathrm{HCV}$ & G1_NS4b̄_1876 & VDLLVNLLPAILSPGA & 2.75 & 16 & $>90 \%$ & $>90 \%$ \\
\hline 465 & 3 & $\mathrm{HCV}$ & G1_NS5b_2879 & LGNIIQRLHGLSAFSLHSY & 2.85 & 15 & $>90 \%$ & $>90 \%$ \\
\hline 466 & 4 & $\mathrm{HCV}$ & G1_NS4b_1769 & ISGIQYLAGLSTLPGNPA & 2.54 & 11 & $>90 \%$ & $>90 \%$ \\
\hline 467 & 5 & $\mathrm{HCV}$ & G1 NS4b 1941 & AARVTQILSSLTITQLLKRLHQWI & 2.33 & 23 & $>90 \%$ & $>80 \%$ \\
\hline 468 & 6 & $\mathrm{HCV}$ & G1_NS5b_2440 & KLPINALSNSLLRHH & 3.00 & 8 & $>90 \%$ & $>80 \%$ \\
\hline 469 & 7 & $\mathrm{HCV}$ & G1_NS4b_1725 & AEQFKQKALGLLQTASRQAE & 1.76 & 12 & $>90 \%$ & $>80 \%$ \\
\hline 470 & 8 & $\mathrm{HCV}$ & G1āanS5)_2485 & LQVLKEVKAAASKVKANL & 2.14 & 11 & $>90 \%$ & $n s^{a}$ \\
\hline 471 & 9 & $\mathrm{HCV}$ & G1_NS4b_1790 & LMAFTAAVTSPLTTS & 2.55 & 18 & $>80 \%$ & $>80 \%$ \\
\hline 472 & 10 & $\mathrm{HCV}$ & G1_NS5b_2840 & WARMILMTHFFSVLIARDQLEQ & 1.96 & 14 & $>80 \%$ & $>80 \%$ \\
\hline 473 & 11 & $\mathrm{HCV}$ & G1 E2 $7 \overline{32}$ & AYCLWMMLLISQAEAALELIT & 1.87 & 16 & $>80 \%$ & $>70 \%$ \\
\hline 474 & 12 & $\mathrm{HCV}$ & G1a_E1_255 & AAILRRHIDLLVGSATLCSALY & 2.20 & 13 & $>80 \%$ & ns \\
\hline 475 & 13 & $\mathrm{HCV}$ & G1_NS3_1605 & DQMWKCLIRLKPTLHGPTP & 2.30 & 15 & $>70 \%$ & $>80 \%$ \\
\hline 476 & 14 & $\mathrm{HCV}$ & G1_NS5b_2941 & CGKYLFNWAVRTKLKLT & 2.61 & 11 & $>70 \%$ & $>60 \%$ \\
\hline 477 & 15 & $\mathrm{HCV}$ & G1a_E1_359 & GIAYFSMVGNWAKVL & 2.75 & 5 & $>70 \%$ & ns \\
\hline 478 & 16 & $\mathrm{HCV}$ & G1a_NS2_909 & VPYFVRVQGLLRICALARKAV & 2.58 & 24 & $>60 \%$ & ns \\
\hline 479 & 17 & $\mathrm{HCV}$ & G1b_NS5b_2898 & PGEINRVASCLRKLGVPPLRAY & 2.31 & 12 & ns & $>80 \%$ \\
\hline 480 & 18 & $\mathrm{HCV}$ & G1b_NS5b_2913 & VPPLRVWRHRARSVRAKLLSQGGRA & A 1.90 & 16 & ns & $>70 \%$ \\
\hline 481 & 19 & $\mathrm{HCV}$ & G1b_NS2_7̄48 & LENLVVLNAASVAGAHW & 2.54 & 17 & ns & $>60 \%$ \\
\hline
\end{tabular}

482

483

484

485

486 
Table III. Predicted, HCV class-I restricted epitopes bind HLA-A*0201

\begin{tabular}{|c|c|c|c|}
\hline 488 & Peptide ID\# & Sequence & $\mathrm{IC}_{50}$ \\
\hline 490 & 1 & HCV_G1_NS4b_1917 & \\
\hline 491 & 2 & HCV_G1a_NS5b_2734 & \\
\hline 492 & 3 & HCV_G1_NS4b_1765 & \\
\hline 493 & 4 & HCV_G1_NS3_1451 & \\
\hline 494 & 5 & HCV_G1b_NS5b_2829 & \\
\hline 495 & 6 & HCV_G1_E2_615 & \\
\hline 496 & 7 & HCV_NS3_1586 & \\
\hline 497 & 8 & HCV_G1_E2_685 & \\
\hline 498 & 9 & HCV_G1_core_133 & \\
\hline 499 & 10 & HCV_G1_NS3_1074 & \\
\hline 500 & 11 & HCV_G1_E1_323 & \\
\hline 501 & 12 & HCV_G1_E1_364 & \\
\hline 502 & 13 & HCV_G1_NS3_1274 & \\
\hline 503 & 14 & HCV_G1_NS4b_1808 & \\
\hline 504 & 15 & HCV_G1_NS3_1607 & \\
\hline 505 & 16 & HCV_G1_NS5b_2559 & \\
\hline 506 & 17 & HCV_G1_E1_277 & \\
\hline 507 & 18 & HCV_G1_E1_281 & \\
\hline 508 & 19 & HCV_G1_NS5b_2945 & \\
\hline 509 & 20 & HCV_G1_NS4b_1769 & \\
\hline 510 & 21 & HCV_G1_NS3_1326 & \\
\hline
\end{tabular}

511 The peptides listed exhibited: $\mathrm{IC}_{50}$ high $\left(\mathrm{IC}_{50}<5 \mu \mathrm{M}\right.$, black bar);

512 moderate $\left(5 \mu \mathrm{M}<\mathrm{IC}_{50}<50 \mu \mathrm{M}\right.$, gray bar $)$ or no $\left(\mathrm{IC}_{50}>100 \mu \mathrm{M}\right.$; white

513 bar) affinity for HLA-A*0201 in a competitive binding assay. 
517 Table IV. Promiscuous, class II-restricted HCV ICS bind multiple HLA-DRB1 alleles

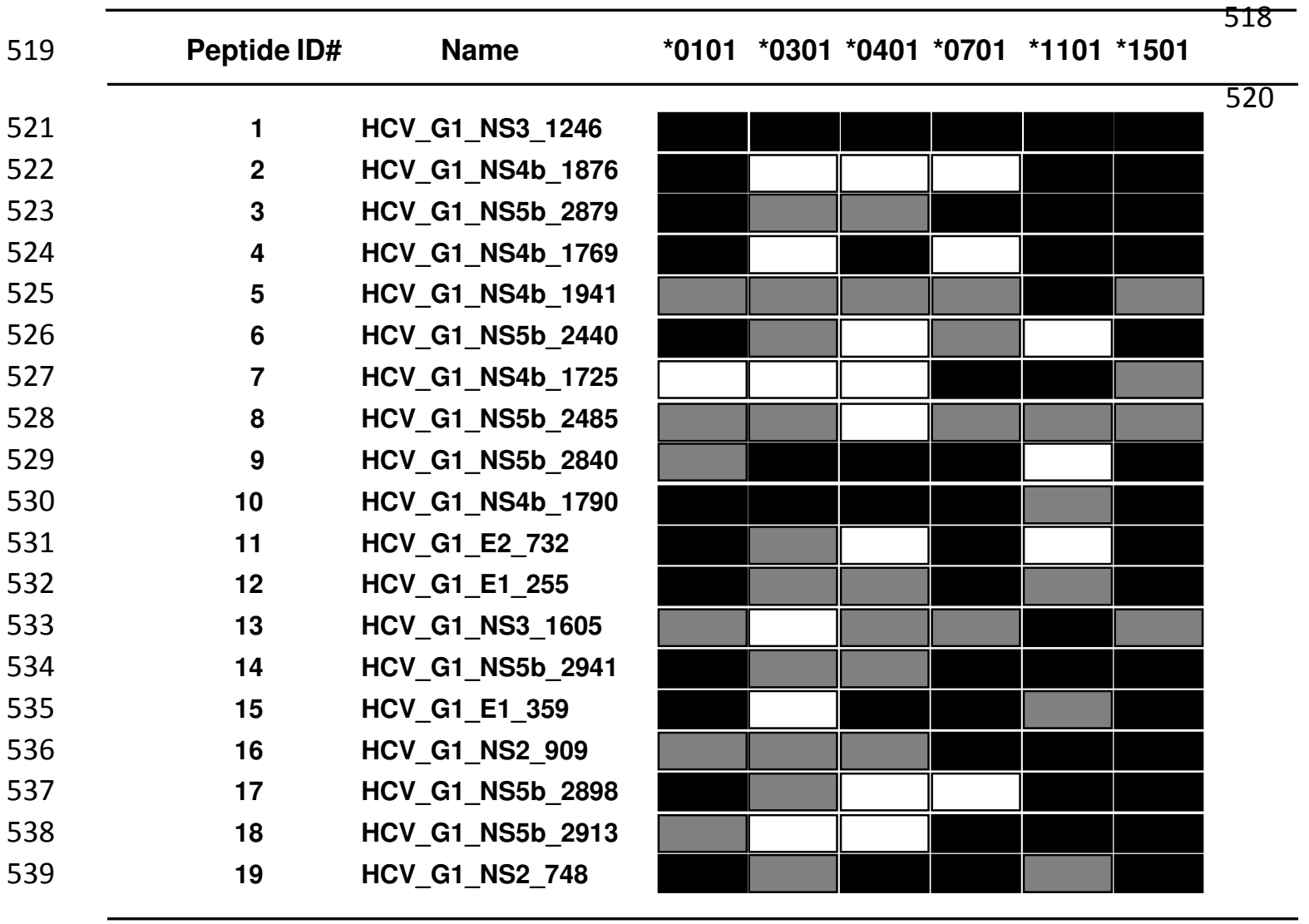

540

541 The peptides listed exhibited: $\mathrm{IC}_{50}$ high $\left(\mathrm{IC}_{50}<10 \mu \mathrm{M}\right.$, black bar); moderate (10

$542 \mu \mathrm{M}<\mathrm{IC}_{50}<100 \mu \mathrm{M}$, gray bar) or low $\left(\mathrm{IC}_{50}>100 \mu \mathrm{M}\right.$; white bar) affinity for the alleles

543 denoted in a competitive binding assay.

544 


\section{$544 \quad$ Figure Legends}

545 Figure 1. Predicted HLA-A*0201- and HLA-DRB1-restricted HCV peptides induce epitope-specific

546 IFN-y production by naïve human PBMCs. PBMCs back-flushed from whole-blood leukocyte

547 reduction filters were cultured with the HLA-A*0201-restricted (top) or HLA-DRB1-restricted (bottom)

548 peptides listed. The cells were collected after 14 days incubation and IFN-y ELISpot assays were

549 performed. Each bar represents the average of triplicate wells minus the average negative control

$550(0.1 \%$ DMSO +2 SD) and the analysis of cells obtained from 5 and 9 healthy donors are shown in

551 the top and bottom panels, respectively.

552 Figure 2. Peptide-pulsed DCs induce HCV epitope-specific IFN-ץ production by naïve human T

553 cells. Purified T cells were co-cultured with monocyte-derived DCs pulsed with the HLA-A2-

554 restricted (top) and HLA-DRB1-restricted (bottom) peptides listed. The sensitized T cells were

555 collected after 14 days and mixed with fresh, peptide-pulsed DCs and IFN-y ELISpot assays were

556 performed. Each bar represents the average of triplicate wells minus the average negative control

$557(0.1 \%$ DMSO +2 SD) and the analysis of cells obtained from 6 and 8 healthy donors shown in the 558 top and bottom panels, respectively. 

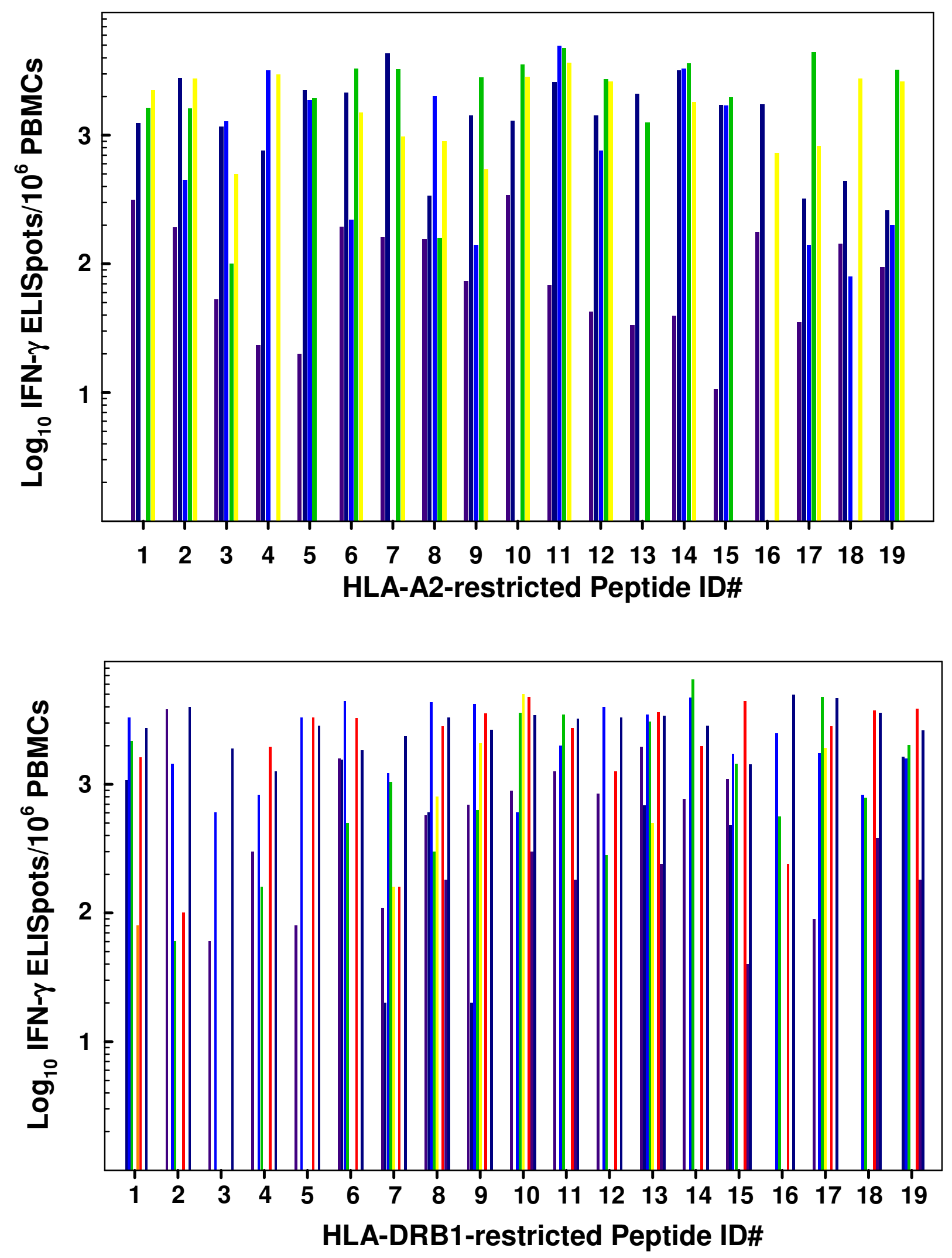


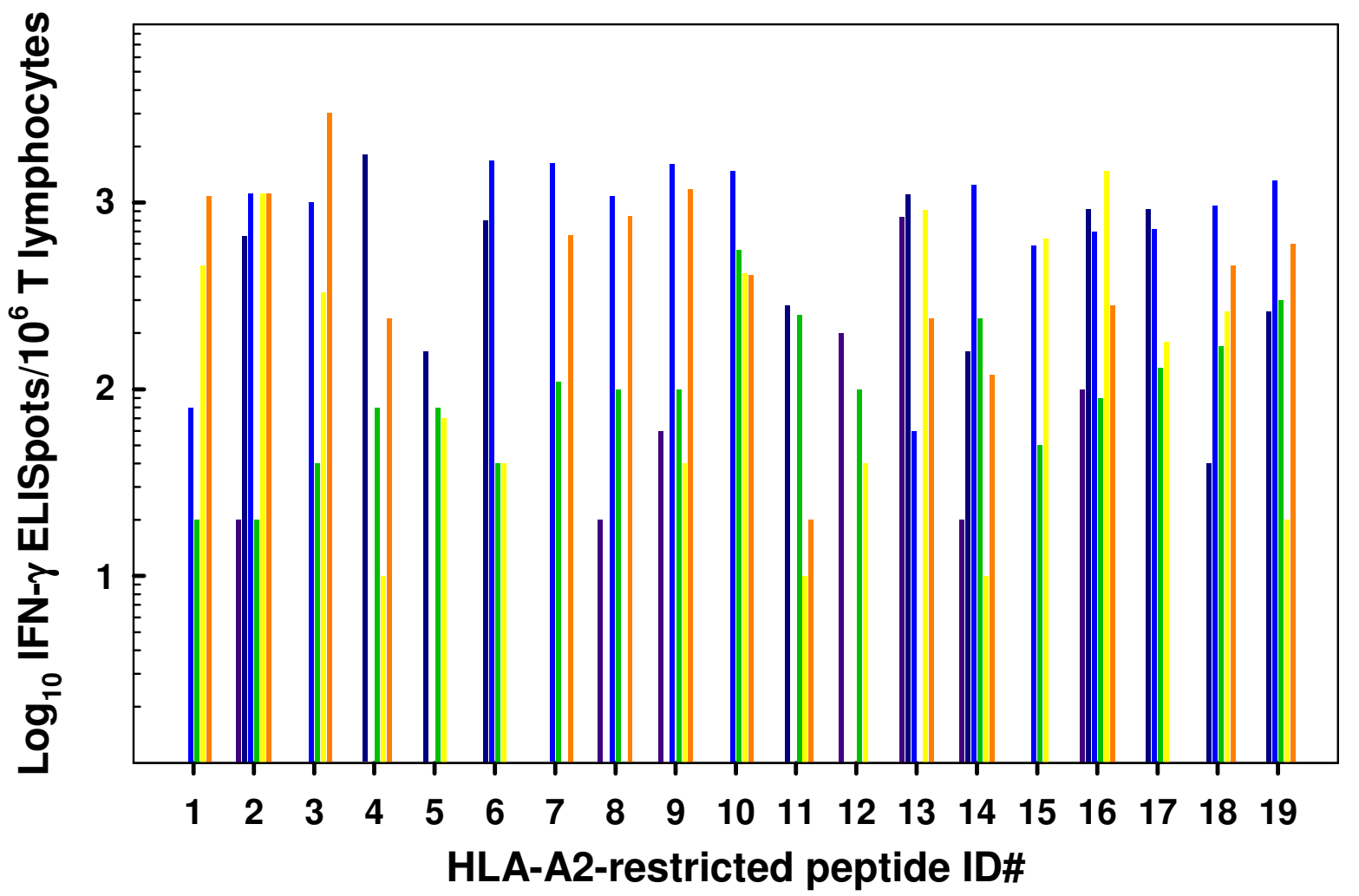

593

594

595

596

597

598

599

600

601

602

603

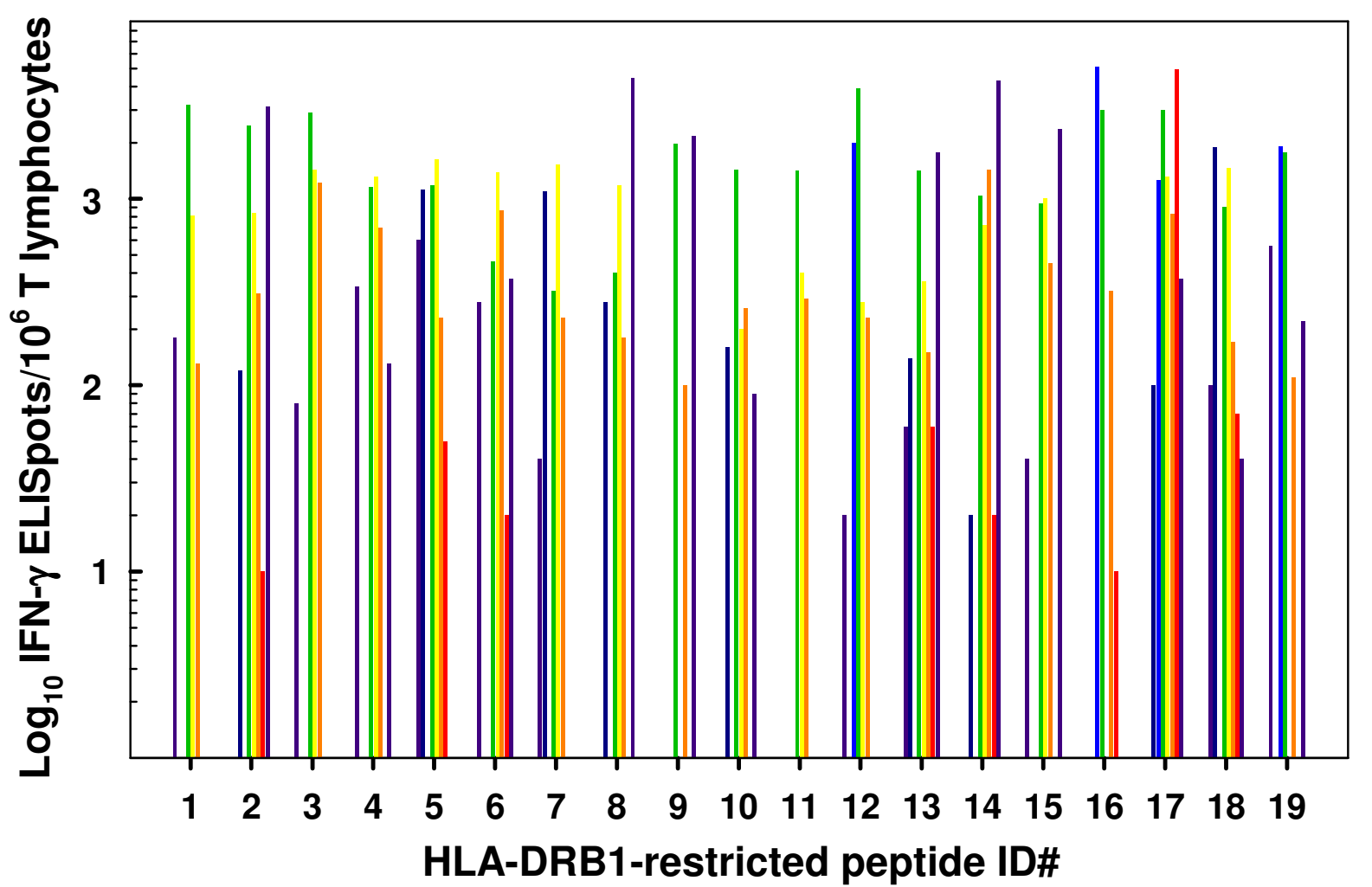

